\title{
OPTIMALISASI TAMAN BACA GAMPONG BUKU PAGA DALAM UPAYA MENGGALAKKAN GERAKAN LITERASI MASYARAKAT DI DESA PAYA GABOH
}

\section{OPTIMIZATION OF PARK READING GAMPONG PAGA BOOK IN AN EFFORT TO SUPPORT THE LITERATURE MOVEMENT COMMUNITY IN PAYA GABOH VILLAGE}

\author{
Nuraina $^{1)}$, Marhami $^{2}$, Sirry Alvina ${ }^{3)}$, Riska Imanda $^{4}$, Faradhillah $^{5)}$ \\ ${ }^{1,2}$ Pendidikan Matematika, FKIP, Universitas Malikussaleh, \\ ${ }^{3,4}$ Pendidikan Kimia, FKIP, Universitas Malikussaleh \\ ${ }^{5}$ Pendidikan Fisika, FKIP, Universitas Malikussaleh \\ ${ }^{5}$ Email: faradhillah@unimal.ac.id
}

\begin{abstract}
Abstrak: Sebelum Covid-19 Warga Desa Paya Gaboh memiliki kegiatan harian seperti pengajian bagi anak-anak, pemuda-pemudi dan ibu/bapak, kegiatan olahraga seperti sepakbola, bola volly dan lain-lain. Pada masa pandemi seperti sekarang ini kegiatan-kegiatan tersebut sedikit dibatasi, sehingga disela-sela aktivitas, masih terdapat beberapa warga yang kurang memanfaatkan waktu, hal ini terlihat banyaknya anak-anak yang hanya duduk-duduk di balai dan di warungwarung dengan bermain HP. Selain itu di Desa Paya Gaboh belum memiliki sebuah pustaka atau ruang yang berisi kumpulan buku-buku yang dapat dimanfaatkan masyarakat untuk membaca sebagai upaya membentuk wawasan yang luas dan memanfaatkan waktu luang dengan hal yang bermanfaat, untuk itu diperlukan taman/ruang baca gampong dalam upaya menggalakkan gerakan literasi msyarakat di desa tersebut. Adapun metode yang digunakan dalam pengabdian ini terdiri dari 5 tahap, yaitu: Tahapan pertama, melakukan pendekatan masyarakat; Tahap kedua, malakukan pengambilan data awal; Tahap tiga, melakukan identifikasi masalah; Tahap keempat, melakukan analisa dari setiap masalah; Tahap terakhir, menentukan solusi. Solusinya adalah membentuk sebuah taman baca gampong. Luaran yang dihasilkan dalam pengabdian ini yaitu Taman Baca Gampong Buku Paga. Adapun hasil evaluasi diperoleh presentase rata-rata diatas $85 \%$ peritemnya, menunjukkan bahwa program taman baca dapat digunakan dengan baik. Kemudian tentang minat baca diperoleh presentase diatas $86 \%$ peritemnya, itu menunjukkan bahwa minat baca masyarakat bagus. Dan yang terakhir mengenai parstisipasi masyarakat mendapat presentase rata-rata diatas 92\% peritemnya, hal ini menunjukkan bahwa masyarakat senang dan antusias sehingga banyak yang ikut berpartisipasi dalam taman baca tersebut. Dengan demikian taman baca yang telah dibuat dalam kegiatan pengabdian ini sangat bermanfaat bagi masyarakat gampong Payah Gaboh.
\end{abstract}

Kata Kunci: Gerakan literasi, Taman baca, Gampong buku, Masyarakat, Paya Gaboh 
Abstract: Before Covid-19, the residents of Paya Gaboh Village had daily activities such as recitations for children, young people and mothers/fathers, sports activities such as football, volleyball and others. During the current pandemic, these activities are slightly limited, so that on the sidelines of activities, there are still some residents who do not take advantage of their time, this can be seen by the number of children just sitting in the hall and in the stalls playing with their handphones. In addition, Paya Gaboh Village does not yet have a library or room that contains a collection of books that can be used by the community to read as an effort to form broad insights and take advantage of free time with useful things. community literacy movement in the village. The method used in this service consists of 5 stages, namely: The first stage is to approach the community; The second stage, carry out initial data collection; Stage three, identify the problem; The fourth stage is to analyze each problem; The last stage, determine the solution. The solution is to form a village reading garden. The output produced in this service is Taman Baca Gampong Buku Paga. The evaluation results obtained an average percentage above $85 \%$ per item, indicating that the reading garden program can be used properly. Then about reading interest, the percentage is above $86 \%$ per item, it shows that people's interest in reading is good. And finally, regarding community participation, the average percentage is above $92 \%$ per period, this shows that the community is happy and enthusiastic so that many participate in the reading park. Thus the reading garden that has been created in this service activity is very useful for the people of Payah Gaboh village.

Keywords: Literacy movement, Reading gardens, Gampong buku, Community, Paya Gaboh

\section{PENDAHULUAN}

Malikussaleh yang berbatasan utara kawasan kampus Unimal Reuleut. Desa Paya Gaboh memiliki jumlah penduduk sekitar 240 kartu keluarga dengan berbagai macam profesi diantaranya PNS, tenaga kontrak, buruh bangunan, serta petani yang menjadi profesi utama rata-rata penduduk desa.

Berdasarkan hasil observasi dan wawancara yang dilakukan dengan keuchik gampong Paya Gaboh bahwa masyarakat desa hanya memanfaatkan waktu luangnya dengan berbagai aktivitas yang tidak bermanfaat. Keuchik gampong tersebut sangat mendukung diadakan kegiatan yang bermanfaat untuk meminimalisir aktivitas yang tidak bermanfaat tersebut. Hasil observasi juga menunjukkan bahwa anak-anak di desa tersebut menggunakan waktu sore hari nya hanya untuk nongkrong serta berbagai aktivitas yang kurang bermanfaat lainnya. Hal tersebut dapat diminimalisir dengan menciptakan sebuah taman baca 
INTEGRITAS : Jurnal Pengabdian

Vol 5 No 2 Desember 2021

ISSN 2580 - 7978 (cetak) ISSN 2615 - 0794 (online)

sebagai wadah literasi masyarakat. Literasi berfungsi untuk membantu meningkatkan pengetahuan masyarakat dengan cara membaca berbagai informasi bermanfaat, membantu meningkatkan kualitas penggunaan waktu seseorang sehingga lebih bermanfaat di masa pandemi Covid-19 ini, dimana sekolah tidak berjalan secara efektif. Sutrisna (2020) menyatakan bahwa Budaya Literasi saat pandemi telah menjadi kebutuhan bagi seluruh masyarakat Indonesia. Literasi bertujuan untuk membangun kemampuan interpersonal seseorang akan semakin baik dan kemampuan memahami suatu informasi akan semakin meningkat.

Budaya literasi salam masyarakat merupakan indikator penting untuk meningkatkan prestasi generasi muda dalam mencapai kesuksesan. Literasi sedini mungkin harus disadari karena menjadi modal utama dalam mewujudkan bangsa yang cerdas dan berbudaya, Juditha (2014); Novita, dkk (2021); Sanusi dan Praseteyo (2019); Sumiati dan Wijonarko (2020). Permasalahan yang dihadapi Indonesia yakni rendahnya penguasaan literasi yang dibuktikan melalui survey Programme for International Student Assessment (PISA). Survey menunjukkan Indonesia berada di posisi 60 dari 61 negara dalam penguasaan literasi. Padahal, budaya literasi bermanfaat dalam mewujudkan peran generasi muda dalam aspek pembangunan Negara. Literasi menjadi kecakapan hidup yang menjadikan manusia berfungsi maksimal dalam masyarakat (Marhami dkk, 2020). Kecakapan hidup bersumber dari kemampuan memecahkan masalah melalui kegiatan berpikir kritis. Selain itu, literasi juga menjadi refleksi penguasaan dan apresiasi budaya. Masyarakat yang berbudaya adalah masyarakat yang menanamkan nilai-nilai positif sebagai upaya aktualisasi dirinya. Aktualisasi diri terbentuk melalui interpretasi, yaitu kegiatan mencari dan membangun makna kehidupan. Hal tersebut dapat dicapai melalui penguasaan literasi yang baik.

Taman baca/pustaka mempunyai peran yang sangat penting dalam masyarakat. hal tersebut disebabkan adanya taman baca dapat meminimalisir kelalaian warga dengan aktivitas yang kurang bermanfaat. Adanya taman baca dapat menunjang kemampuan literasi masyarakat dalam menghadapai perubahan dunia secara global seperti sekarang ini. Pentingnya kesadaran berliterasi sangat mendukung keberhasilan seseorang dalam menangani berbagai persoalan. Melalui 
INTEGRITAS : Jurnal Pengabdian

Vol 5 No 2 Desember 2021

ISSN 2580 - 7978 (cetak) ISSN 2615 - 0794 (online)

kemampuan literasi, seseorang tidak saja memperoleh ilmu pengetahuan tetapi juga bisa mendokumentasikan sepenggal pengalaman yang menjadi rujukan di masa yang akan datang (Darmayanti, 2016).

Berdasarkan permasalahan di atas diperlukan sebuah solusi yang baik guna menumbuhkan minat baca serta menciptakan generasi muda yang memiliki kepribadian unggul dan mampu memahami pengetahuan serta teknologi untuk bersaing secara lokal dan global, maka tim pengabdian akan melaksanakan "Optimalisasi Taman Baca Gampong Buku Paga dalam Upaya Menggalakkan Gerakan Literasi Masyarakat di Desa Paya Gaboh Aceh Utara".

\section{METODE}

Pengabdian ini akan dilaksanakan pada bulan Agustus sampai November 2021. Adapun yang menjadi lokasi pengabdian ini adalah Desa Paya Gaboh Kecamatan Sawang Kabupaten Aceh Utara.

Metode pelaksanaan yang dilakukan sebagai pendekatan pada pengabdian masyarakat di Desa Paya Gaboh Kecamatan Sawang Kabupaten Aceh Utara terdiri dari 5 tahap, yaitu: Tahapan petama, melakukan pendekatan masyarakat. Tahap kedua, malakukan pengambilan data awal. Tahap tiga, melakukan identifikasi masalah. Tahap keempat, melakukan analisa dari setiap masalah. Tahap terakhir, menentukan solusi.

Adapun yang menjadi mitra dalam pengabdian ini adalah Desa Paya Gaboh Kecamatan Sawang Kabupaten Aceh Utara. Partisipasi mitra dalam kegiatan ini meliputi: Mitra sebagai penyedia tempat untuk penyelenggaraan kegiatan Optimalisasi Taman Baca yaitu bertempat di desa Paya Gaboh. Mitra berperan sebagai peserta sosialisasi dan aktif berperan dalam kegiatan diskusi/tanya jawab. Mitra terlibat secara keseluruhan dalam program kegiatan pengabdian meliputi perumusan permasalahan, penjadwalan kegiatan, pelaksanaan program kegiatan hingga tahap evaluasi kegiatan. 
INTEGRITAS : Jurnal Pengabdian

Vol 5 No 2 Desember 2021

ISSN 2580 - 7978 (cetak) ISSN 2615 - 0794 (online)

\section{HASIL DAN PEMBAHASAN}

Kegiatan pengabdian ini bertujuan untuk menumbuhkan minat baca masyarakat di desa Paya Gaboh, tingginya minat baca sangat dibutuhkan oleh setiap orang, terutama bagi kalangan anak-anak dan remaja. Oleh karena itu dibutuhkan berbagai cara untuk meningkatkan minat baca masyarakat ini salah satunya melalui Taman Baca Gampong Buku Paga. Taman baca desa ini juga dapat dijadikan sarana untuk masyarakat dalam menghabiskan waktu luangnya dengan kegiatan lebih bermanfaat.

Keberadaan Taman Baca Gampong Buku Paga memiliki peran yang sangat besar dalam menarik dan menumbuh kembangkan minat membaca di kalangan masyarakat selain itu pengadaan Taman Baca Gampong Buku Paga bertujuan untuk membentuk sebuah taman baca gampong dalam upaya menciptakan generasi muda yang mempunyai kesadaran berliterasi di Desa Paya Gaboh Aceh Utara. Kegiatan tersebut telah terlaksana sesuai dengan program yang ditentukan dan diharapkan oleh tim pengabdian yang dimulai dari bulan Juli hingga November 2021. Keseluruhan kegiatan yang dirancang telah dilakukan oleh tim pengabdian dosen yang terdiri 1 orang ketua dan 4 orang anggota yang terdiri dari 3 bidang ilmu yang bergabung dalam satu tim yaitu bidang ilmu pendidikan matematika, pendidikan fisika, dan ilmu pendidikan kimia.

Kegiatan tahap awal yang dilakukan tim pengabdian ialah melakukan pendekatan masyarakat dengan cara merespon keluhan masyarakat tentang proses belajar secara daring yang disebabkan oleh dampak Covid-19 yang berakibat pada menurunnya keinginan belajar anak-anak dan menghabiskan banyak waktu hanya untuk bermain gadget dan nongkrong di warung. Kemudian berdasarkan data awal, fakta dan keluhan tersebut tim mengambil kesimpulan bahwa Desa Paya Gaboh belum mengoptimalisasi ruang atau tempat membaca yang disediakan desa untuk membangkitkan minat Literasi Masyarakat di desa tersebut. Melihat permasalahan tersebut tim melakukan diskusi dengan penjabat desa setempat. Dari hasil diskusi tersebut bahwa perlu adanya pengoptimalisasian ruang/taman baca sehingga disepakati akan dilaksanakan kegiatan optimalisasi ruang/taman baca di Desa 
Paya Gaboh, dengan memberikan pendampingan untuk menjelaskan cara membaca yang benar dan bermakna.

Tahap kegiatan selanjutnya tim melakukan penyiapan Taman Baca Gampong Buku Paga pada ruang/taman baca dengan menata berbagai macam judul buku di rak buku, serta menata ruangan sedemikin rupa sehingga dapat menarik minat baca para pemuda-pemudi dan anak-anak masyarakat Desa Paya Gaboh dan minat untuk mengunjungi Taman Baca Gampong Buku Paga. Untuk membuka pemikiran masyarakat tentang pentingnya literasi dan meningkatkan minat literasi masyarakat tersebut tim pengabdian melakukan sosialisasi pengenalan literasi dengan pendekatan pada masyarakat Desa Paya Gaboh. Gambar penyerahan buku dan gambar taman baca gampong buku paga desa Paya Gaboh dapat dilihat pada gambar berikut:

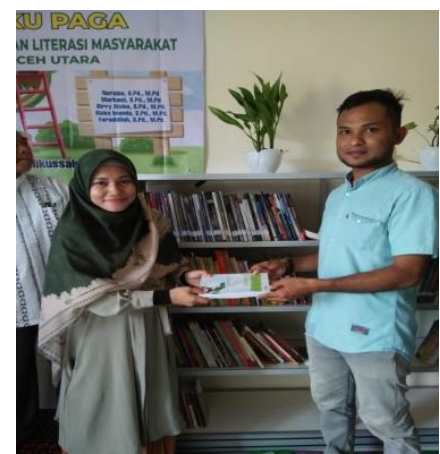

(a)

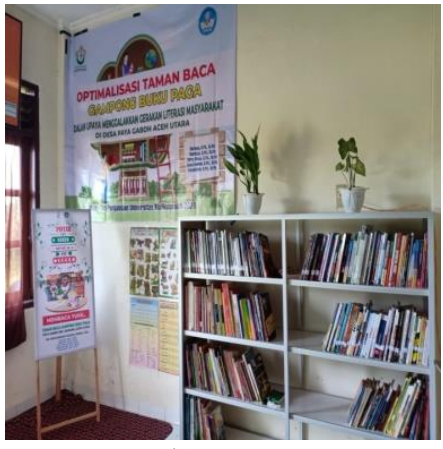

(b)

Gambar 1. (a) Penyerahan taman baca dan (b) Taman Baca Gampong Buku Paga

Gambar 1 (a) di atas adalah penyerahan buku diberikan langsung oleh ketua tim pelaksana pengabdian yaitu Ibu Nuraina, S.Pd., M.Pd. kepada Bapak Zulfahmi selaku keuchik Desa Paya Gaboh disaksikan oleh perangkat desa lainnya seperti sekretaris desa, tuha peut dan anggota tim pelaksana pengabdian pada tanggal 23 November 2021. Gambar 1 (b) adalah foto taman baca gampong buku paga, buku yang diserahkan oleh tim terdiri dari berbagai kategori, seperti buku agama, kesehatan masyarakat, buku pertanian, peternakan, enterprener, buku kategori anak-anak dari usia PAUD, TK, SD, SMP dan SMA dan lain-lain. Buku yang tersedia bisa dimanfaatkan oleh segala usia. Dengan adanya taman baca ini anak-anak dapat semangat lagi dalam belajar terlebih pada masa pandemi saat ini. 
Selanjutnya orang tua juga dapat mendampingi anak untuk menciptakan rasa cintanya terhadap literasi membaca. Taman baca ini di décor oleh tim pelaksana pengabdian dengan mengutamakan kenyamanan, kebersihan tempat, desain yang menarik, penataan ruangan taman baca yang bagus sehingga taman baca ini dapat menarik minat pengunjung, dengan suasana yang nyaman dan bersih dapat memotivasi masyarakat untuk berkunjung dan membaca koleksi di taman baca tersebut.

Tahap berikutnya adalah sosialisasi dan pendampingan masyarakat di taman baca. Kegiatan sosialiasi merupakan serangkaian kegiatan yang dilakukan setelah kegiatan menyiapkan taman baca selesai dilaksanakan. Pada tahapan ini masyarakat diberikan pelatihan berupa pemaparan materi berkaitan dengan pentingnya literasi bagi masyarakat khususnya anak-anak usia sekolah. Materi literasi langsung diberikan oleh anggota tim pelaksana pengabdian yaitu Ibu Sirry Alvina, S.Pd., M.Pd. Kegiatan ini didominasi anak-anak usia sekolah, mereka sangat antusias mengikuti kegiatan tersebut. Masyarakat di desa tersebut juga merasa senang dengan tujuan akhir dari diadakannya pendampingan ini yaitu adanya taman baca gampong buku paga. Hal ini dikarenakan di Desa Paya Gaboh belum adanya perpustakaan desa sebelumnya. Berikut ini gambar kegiatan sosialisasi dilakukan.

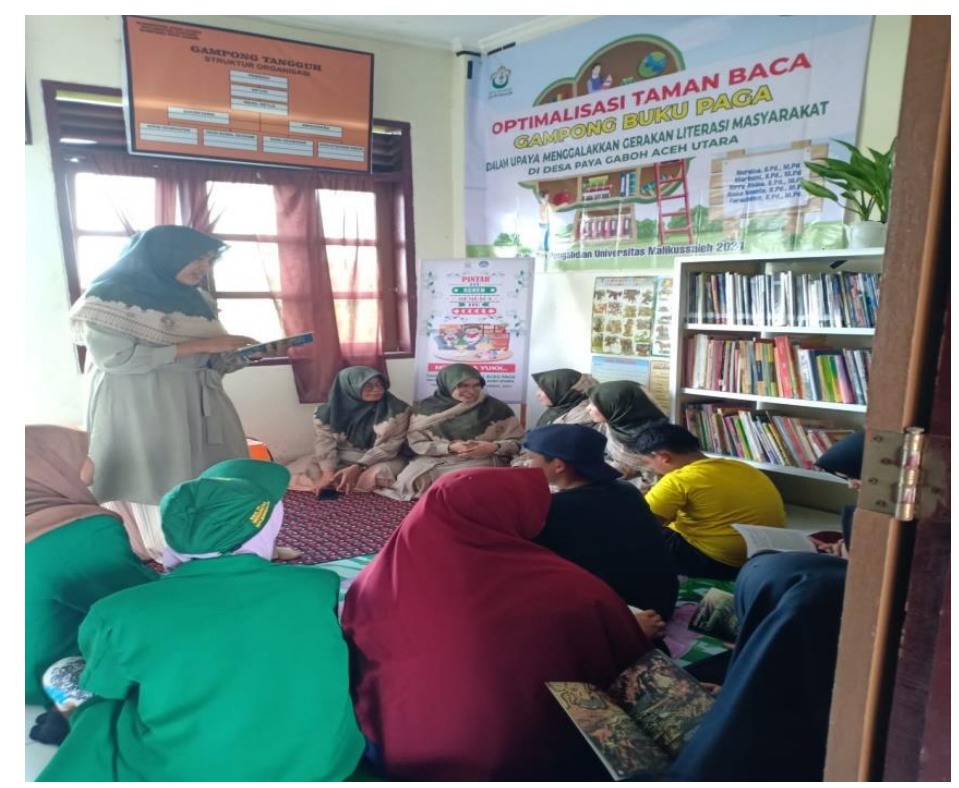

Gambar 2. Sosialisasi literasi kepada masyarakat 
Kegiatan berikutnya adalah pendampingan. Pendampingan merupakan kegiatan lanjutan dimana masyarakat mengerti dan memahami pentingnya budaya literasi. Literasi juga dapat meningkatkan hasil belajar anak jika orang tua dapat mendampingi dan ikut serta berusaha untuk melek baca dan memberikan dorongan bagi anak untuk belajar. Berikut foto pendampingan di taman baca.

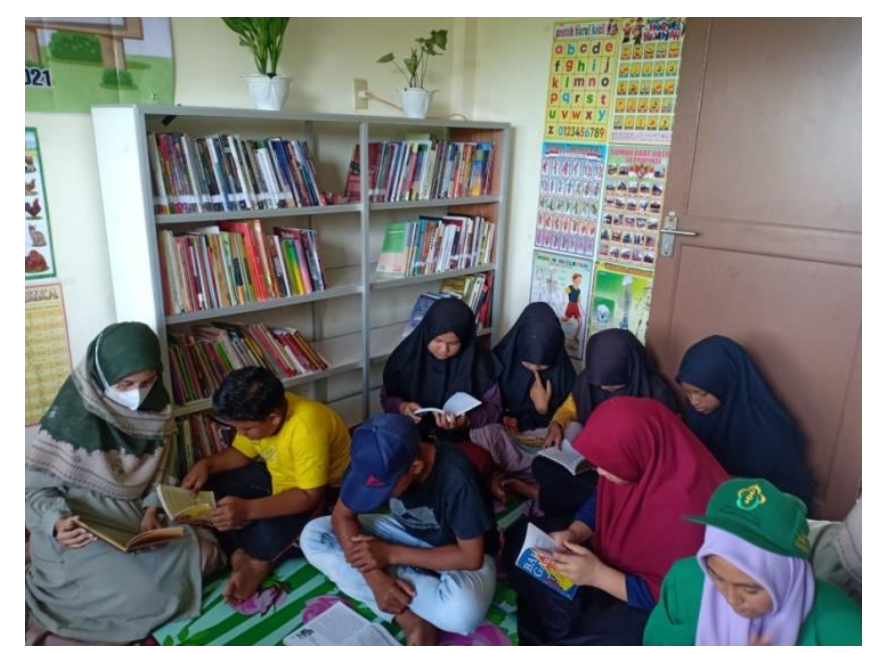

Gambar 3. Pendampingan literasi kepada masyarakat

Kegiatan pendampingan ini dilaksanakan oleh anggota tim pelaksana pengabdian yaitu Ibu Marhami, S.Pd., M.Pd., Ibu Riska Imanda, S.Pd., M.Pd., dan Ibu Faradhillah, S.Pd., M.Pd. Tujuan dilaksanakan pendampingan ini adalah agar masyarakat dan anak-anak usia sekolah di Desa Paya Baboh khususnya anak-anak usia sekolah dapat membaca buku dengan benar dan semangat membaca bukubuku yang ada di taman baca tersebut. Dengan demikian nantinya orangtua dapat mendampingi dan mengarahkan anak untuk lebih banyak membaca buku dan semangat kembali dalam belajar.

Hasil dari seluruh kegiatan ini selain pendekatan yang dilakukan oleh tim bekerja sama dengan perangkat desa mengenai pengenalan literasi kepada masyarakat, pada pengabdian ini tim malakukan evaluasi dengan cara menganalisis kondisi mitra setelah program dilaksanakan. Instrumen evaluasi yang digunakan adalah angket respon masyarakat.

Angket respon masyarakat ini terdiri dari 32 responden yang diberikan pada masyarakat. Hasil angket dapat dilihat pada tabel berikut: 
Tabel 1. Hasil Angket Masyarakat

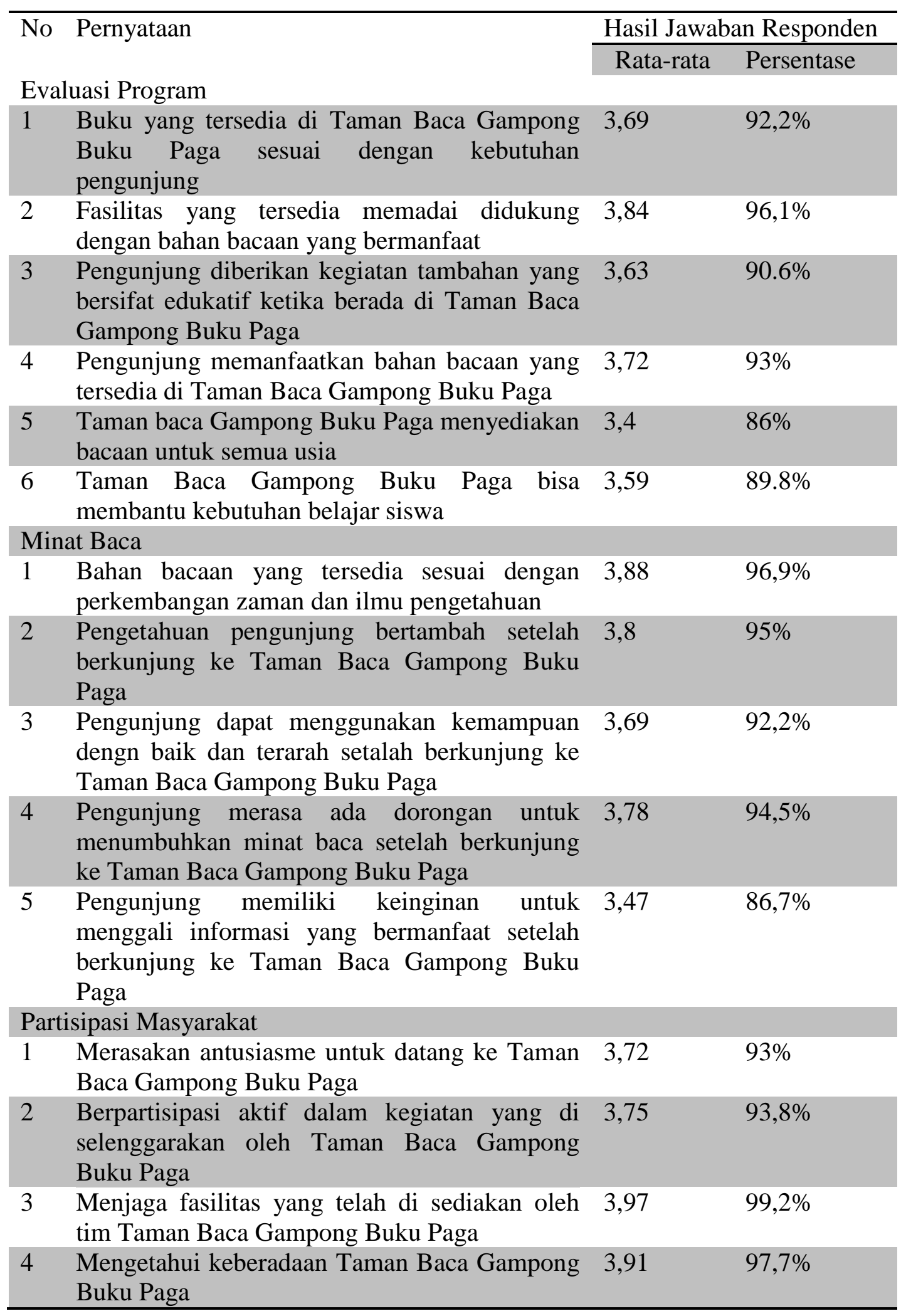


Pernyataan yang terdapat pada angket dimulai dari mengenai evaluasi program yang terdiri dari mengenai ketersedian buku yang sesuai dengan pengunjung serta untuk semua usia, fasilitas yang tersedia memadai didukung dengan bahan bacaan yang bermanfaat, kegiatan yang edukatif pada saat berada di taman baca dan taman baca ini membantu kebutuhan belajar siswa. Secara keselurahan rata-rata responden memberi penilaian sangat setuju dan setuju terhadap pernyataan yang terdapat diangket. Hal tersebut dapat dilihat hasil perhitungan angket yang telah diberikan ke masyarakat dimana nilai rata-rata peritem pernyataan didapat nilai rataan diatas 3,3 dengan persentase diatas $85 \%$ peritem pernyataannya.

Angket yang diberikan juga terdapat pernyataan mengenai minat baca masyarakat Gampong Payah Gaboh yang terdiri dari 5 pernyataan. Respon yang diberi oleh 32 responden ialah sangat setuju dan setuju terhadap 5 pernyataan. Hal tersebut dapat dilihat hasil perhitungan angket didapat nilai rataan diatas 3,45 dengan persentase diatas $86 \%$ peritem pernyataannya. Dimana bahan bacaan yang tersedia sesuai dengan perkembangan zaman serta ilmu pengetahuan, para pengunjung "Taman Baca Gampong Buku Paga" dapat menggunakan kemampuan dengan baik dan terarah, pengunjung juga merasa meningkatnya minat baca, dan serta memiliki keinginan untuk menggali informasi yang lebih lagi.

Isi dari angket yang terakhir ialah mengenai partisipasi masyarakat terhadap "Taman Baca Gampong Buku Paga". Hasil perhitungan yang didapat dari angket ialah nilai rataan diatas 3,7 dengan persentase diatas $92 \%$ peritem pernyataannya. Hal ini menunjukkan bahwa partisipasi masyarakat terhadap "Taman Baca Gampong Buku Paga" sangat tinggi, dimana masyarakat memiliki antusias untuk mengunjungi taman baca, berpartisipasi dalam kegiatan yang ada di taman baca, menjaga fasilitas taman baca, dan mengetahui keberadaan "Taman Baca Gampong Buku Paga”. 
INTEGRITAS : Jurnal Pengabdian

Vol 5 No 2 Desember 2021

ISSN 2580 - 7978 (cetak) ISSN 2615 - 0794 (online)

\section{KESIMPULAN}

Adapun kesimpulan dari kegiatan pengabdian Optimalisasi Taman Baca Gampong Buku Paga Dalam Upaya Menggalakkan Gerakan Literasi Masyarakat di Desa Payah Gabo Aceh Utara yaitu dengan dibangunnya Taman Baca Gampong Buku Paga dapat membuat masyarakat memanfaatkan waktu luangnya dengan mengunjungi Taman Baca Gampong Buku Paga tersebut, sehingga masyarakat dan anak-anak sekolah dasar maupun menengah bisa menghabiskan waktu dengan kegiatan yang bermanfaat dengan membaca buku dan mencari informasi. Dengan hal tersebut dapat meningkat kemampuan literasi pada masyarakat Paya Gaboh. Adapun hasil evaluasi dapat dilihat dari hasil angket yang dibagikan mulai dari evaluasi program mendapatkan presentase rata-rata diatas $85 \%$ peritemnya, itu menunjukkan bahwa program taman baca dapat digunakan dengan baik. Kemudian tentang minat baca dengan presentase diatas $86 \%$ peritemnya, hal itu menunjukkan bahwa minat baca masyarakat bagus dengan adanya taman baca yang telah dibangun. Dan yang terakhir mengenai pastisipasi masyarakat mendapat presentase rata-rata diatas $92 \%$ peritemnya, hal ini menunjukkan bahwa masyarakat senang dan antusias sehingga banyak yang ikut berpartisipasi dalam taman baca tersebut. Dengan demikian taman baca yang telah dibuat dalam kegiatan pengabdian ini dapat bermanfaat bagi masyarakat gampong Payah Gabo Aceh Utara dari generasi ke generasi.

\section{UCAPAN TERIMA KASIH}

Pelaksanaan Program Pengabdian Kepada Masyarakat ini dapat terlaksana karena adanya dukungan dari beberapa pihak terkait yaitu:

1. Pihak Lembaga Penelitian dan Pengabdian Kepada Masyarakat (LPPM) Universitas Malikussaleh yang telah memberikan dukungan berupa moril dan materiil. Dukungan moril berupa kepercayaan LPPM kepada dosen untuk melakukan program pengabdian masyarakat. Dukungan materiil yaitu pemberian dana operasional dalam skema dana hibah pengabdian kepada masyarakat tahun anggaran Semester Ganjil 2021/2022 untuk terlaksananya program pengabdian masyarakat sesuai dengan pengajuan oleh tim pengusul program pengabdian kepada masyarakat. 
2. Pihak Desa Paya Gaboh telah memberikan kesempatan kepada tim pelaksana program pengabdian kepada masyarakat sehingga dapat mengimplementasikan kegiatan pengabdian kepada masyarakat berkaitan dengan Gerakan literasi Masyarakat Desa Paya Gaboh.

\section{DAFTAR PUSTAKA}

Darmayanti, R. 2016. Membangun Budaya Literasi Informasi Bagi Masyarakat Kampus, Jurnal I'raq, 10(1)

Eti Sumiati, Wijonarko. 2020. Manfaat Literasi Digital Bagi Masyarakat Dan Sektor Pendidikan Pada Saat Pandemi Covid-19, Buletin Perpustakaan Universitas Islam Indonesia, 3(2) 2020, 65-80

Juditha, C. 2014. Tingkat Literasi Media Masyarakat Di Wilayah Perbatasan Papua, Journal Communication Spectrum, 3(2) : 107-120

Marhami, Lukman, I.R., \& Muliani, 2020. Pengantar Literasi Sains dan Numerasi Penunjang Asesmen Kompetensi Minimum (AKM). Banten: CV.AA. Rizky

Novita, N., Marhami, Sakdiyah, H., \& Muliani. 2021. Pengembangan Kompetensi Literasi Digital Pada Guru untuk Optimalisasi Pembelajrana Jarak Jauh (PJJ), MANTAPPA: Jurnal Pengabdian Kepada Masyarakat, 4(1): 51-58

Sanusi., Prasetyo, A. 2019. Pengenalan Gerakan Literasi Pada Masyarakat, Jurnal Pkm: Pengabdian Kepada Masyarakat, 2(2): 162-166

Sutrisna, I. P. G. 2020. Gerakan Literasi Digital Pada Masa Pandemi Covid-19, Jurnal Pendidikan Bahasa Dan Seni, 8(2). 